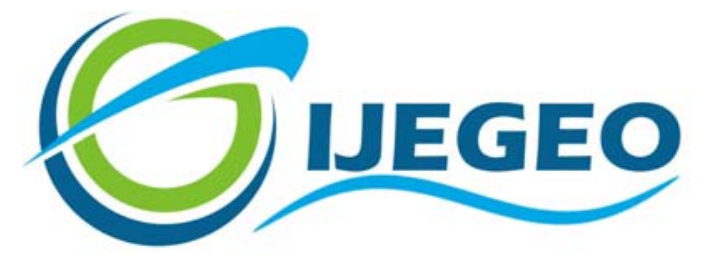

International Journal of Environment and Geoinformatics (IJEGEO) is an international, multidisciplinary, peer reviewed, open access journal.

\title{
Numerical Modelling of the 1995 Dinar Earthquake Effects on Hydrodynamic Regime of Egirdir Lake Murat Aksel and Sedat Kabdaşlı
}

\section{Editors}

Prof. Dr. Cem Gazioğlu, Prof. Dr. Dursun Zafer Şeker, Prof. Dr. Ayşegül Tanık, Assoc. Prof. Dr. Şinasi Kaya

\section{Scientific Committee}

Assoc. Prof. Dr. Hasan Abdullah (BL), Assist. Prof. Dr. Alias Abdulrahman (MAL), Assist. Prof. Dr. Abdullah Aksu, (TR); Prof. Dr. Hasan Atar (TR), Prof. Dr. Lale Balas (TR), Prof. Dr. Levent Bat (TR), Assoc. Prof. Dr. Füsun Balık Şanlı (TR), Prof. Dr. Nuray Balkıs Çağlar (TR), Prof. Dr. Bülent Bayram (TR), Prof. Dr. Şükrü T. Beşiktepe (TR), Dr. Luminita BUGA (RO); Prof. Dr. Z. Selmin Burak (TR), Assoc. Prof. Dr. Gürcan Büyüksalih (TR), Dr. Jadunandan Dash (UK), Assist. Prof. Dr. Volkan Demir (TR), Assoc. Prof. Dr. Hande Demirel (TR), Assoc. Prof. Dr. Nazlı Demirel (TR), Dr. Arta Dilo (NL), Prof. Dr. A. Evren Erginal (TR), Dr. Alessandra Giorgetti (IT); Assoc. Prof. Dr. Murat Gündüz (TR), Prof. Dr. Abdulaziz Güneroğlu (TR); Assoc. Prof. Dr. Kensuke Kawamura (JAPAN), Dr. Manik H. Kalubarme (INDIA); Prof. Dr. Fatmagül Kılıç (TR), Prof. Dr. Ufuk Kocabaş (TR), Prof. Dr. Hakan Kutoğlu (TR), Prof. Dr. Nebiye Musaoğlu (TR), Prof. Dr. Erhan Mutlu (TR), Assist. Prof. Dr. Hakan Öniz (TR), Assoc. Prof. Dr. Hasan Özdemir (TR), Prof. Dr. Haluk Özener (TR); Assoc. Prof. Dr. Barış Salihoğlu (TR), Prof. Dr. Elif Sertel (TR), Prof. Dr. Murat Sezgin (TR), Prof. Dr. Nüket Sivri (TR), Assoc. Prof. Dr. Uğur Şanlı (TR), Assoc. Prof. Dr. Seyfettin Taş (TR), Assoc. Prof. Dr. İ. Noyan Yılmaz (TR), Assist. Prof. Dr. Baki Yokeş (TR), Assist. Prof. Dr. Sibel Zeki (TR), Dr. Hakan Kaya (TR).

Abstracting and Indexing: Index Copernicus, Open Academic Journals Index, Scientific Indexing Services 


\title{
Numerical Modelling of the 1995 Dinar Earthquake Effects on Hydrodynamic Regime of Egirdir Lake
}

\author{
Murat Aksel ${ }^{1, *}$, Sedat Kabdaşlı ${ }^{2}$ \\ ${ }^{1}$ Istanbul Kultur University, Engineering Faculty, Civil Engineering Department 34158 TR \\ ${ }^{2}$ Istanbul Technical University, Civil Engineering Faculty, Civil Engineering Department 34485 TR \\ * Corresponding author \\ $\begin{array}{lll}\text { Tel } & \text { : }+902124984260 & \text { Accepted } 30 \text { Nov } 2017\end{array}$ \\ E-mail :m.aksel@iku.edu.tr
}

\begin{abstract}
The effect of earthquakes on closed and semi-closed water systems is a research topic that has been studied for many years. The lack of continuous measurement systems in closed and semi-closed water systems is insufficient to examine and investigate what has happened during the earthquake. The morphological structures of the lakes indicate the characteristics of the events that occurred during an earthquake. Due to the developing technology and research request, some monitoring, measurement stations are installed in some lakes, gulfs, estuaries, etc. systems. Today, both higher quality measurement and field data can be obtained, and more complicated processes are being explored with the help of faster computers. Computational fluid dynamics is currently used because of the difficulty in calculating hydrodynamic responses of lakes due to earthquake. Investigations on the effects of the earthquake condition on the desired closed / semi-closed water system studies by using numerical modelling have been continuing increasingly in recent years. Both the quality of the bathymetric data gathered from the field, the continuous acquisition of both dynamic water level measurement systems, and the use of new technologies and systems in the search for base materials contribute to the fact that we have more knowledge of the formation, behavior and effects of the sorts. In this study, 1995 Dinar Earthquake effects on Egirdir Lake hydrodynamic regime was investigated by numerical modelling approach.
\end{abstract}

Keywords: Earthquake, Lake, Numerical Modelling, Oscillation, Seiche

\section{Introduction}

Earthquakes, as natural hazards, play a significant role in the lives of those who live in seismically active regions (Gulakyan and Wilkinson, 2002). There are rare studies of the effects of earthquakes on Lakes. Turkey is located in a region where major earthquakes are taking place through the geographical location. Over the last hundred years, over 15 major earthquakes in Turkey have been overtaken by violent and destructive events (Hébert et al., 2005; Ambraseys, 2009; Altınok, et al., 2011). Especially 1999 Kocaeli Earthquake is a milestone in terms of the design of earthquake structures and the determination of new construction regulations. The potential impact of the epidemic should be taken into account in environmental and infrastructure planning as well as structural studies (Gökaşan, et al., 2001; Kozac1, et al., 2011).
Earthquake effects should be investigated for the areas like infrastructure facilities, environmental sensitive areas, lakes, coastal facilities and earthquake impact must be considered in the planning process while planning for such areas and facilities.

Lakes are natural and economic resources for human use. Lakes can be used as well as tourism, transportation, fishing, irrigation activities and also as water supply and wastewater disposal. Oscillations can occur due to the effects of the earthquake due to their masses of closed water bodies and lakes. The formation of the waves that occur as a result of these oscillations which is defined as seiche depends on depth, dimensions, earthquake properties and water quality of the lake. 
Effects of earthquakes on lakes are a research topic that has been studied for many years. In the Lodi Earthquake that took place at California in 1932, height of water surface fluctuation was measured as $12-24 \mathrm{~mm}$ in observation wells and stream gaging stations (Piper, 1933). Kvale, who observed seismicinfluenced water mass fluctuations on the Norwegian and British coasts of the 1950 Assam earthquake, called these oscillations as seiche (Kvale, 1955). Kvale expressed that the seiche is related to the depth and dimensions of the lake and indicated two important points for oscillation. First, natural period of the fluid body must be close to the dominant period of the seismic waves and the second, energy of the earthquake must be at a rate to move the fluid body into action. McGarr summarized the parameters that determine the maximum seiche wave amplitude as seismic wave amplitude, depth and the ratio between the period of the seismic waves and the natural period of the water mass (McGarr, 1965). In 2002, the Denali Earthquake (Alaska) caused damage to the vessels, underwater pipelines, mooring systems cause of seicmic seiches in Seattle, Lake Union, (Barberopoulou et al., 2004). In the same earthquake, at Wenatchee Lake, Canada, $1.5 \mathrm{~m}$ long flood was observed on coastal zone due to seiches (Cassidy et al., 2002). Another study on the effects of the seiches were published by Bondevik et al. (2013). Image process was used to detect oscillation of a vessel during Tohoku Earthquake, 2011, induced seiches at Norway
Fjords. Additionally, numerical simulation of oscillation in fjord was performed and the results were compared the image process results. Seiche height and period were indicated as similar.

\section{Methodology \\ Study Area}

Geographical location of Turkey causes massive earthquakes. Lakes Region in southwest side of Turkey is located in the high damage risk area. There are several lakes inside this region and most of them are near residential and agricultural areas.

Egidir Lake was chosen for numerical modeling case study because lake is surrounded by low elevated plains as shown in Fig 2. Egirdir Lake, second largest lake in Lakes Region, is the fourth largest lake in Turkey due to surface area. Egirdir Lake is mostly used for irrigation and surrounded by agricultural areas. The total surface area of Egirdir Basin is $3020 \mathrm{~km}^{2}$ with a total surface area of $468 \mathrm{~km}^{2}$. The maximum water level of the lake was $919.3 \mathrm{~m}$ and the volume of the lake is 4 billion $\mathrm{m}^{3}$. The lake, which is $917.7 \mathrm{~m}$ above the sea level, has an average depth of $10-12 \mathrm{~m}$, varying with years, but it has been determined that the average water depth of the lake decreased to $8-9 \mathrm{~m}$ in later studies. Egirdir Lake is a full mixed lake without thermal stratification.

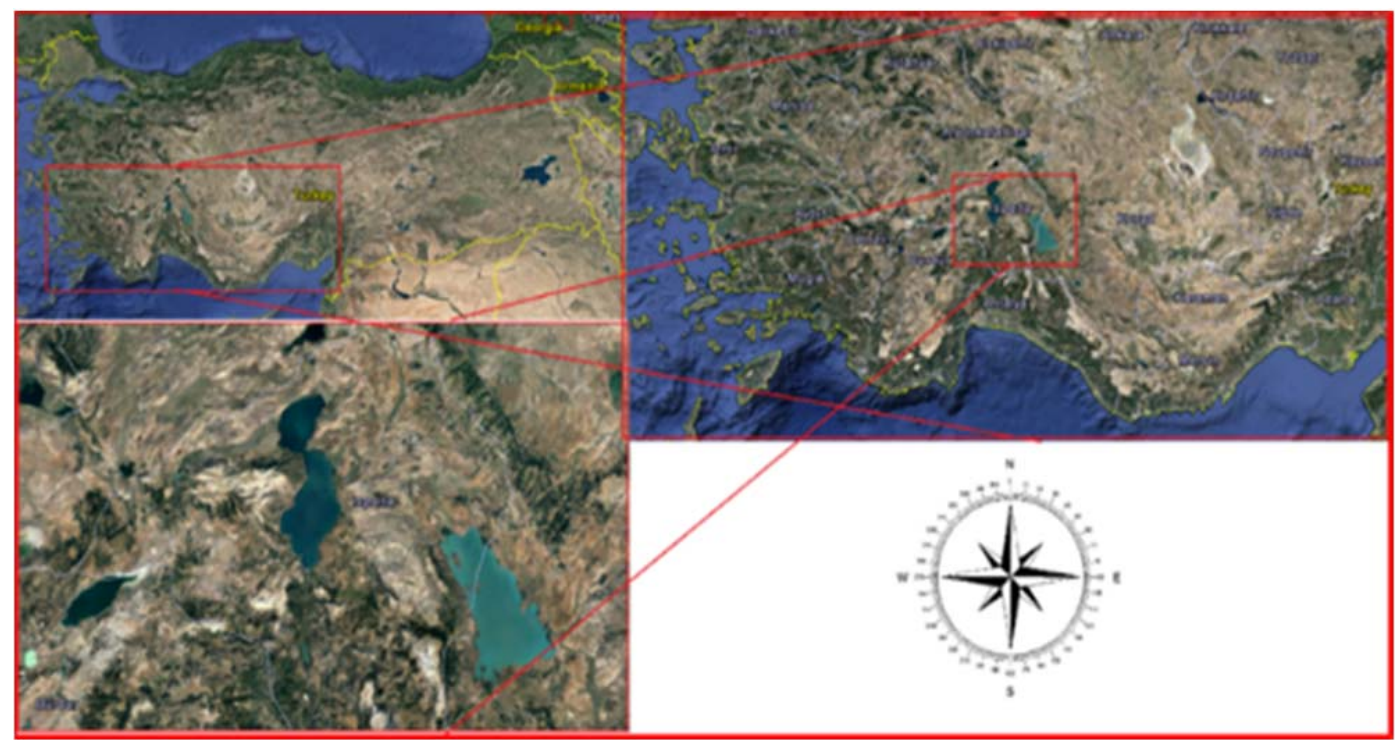

Fig 1. Lakes Region and Egirdir Lake. 


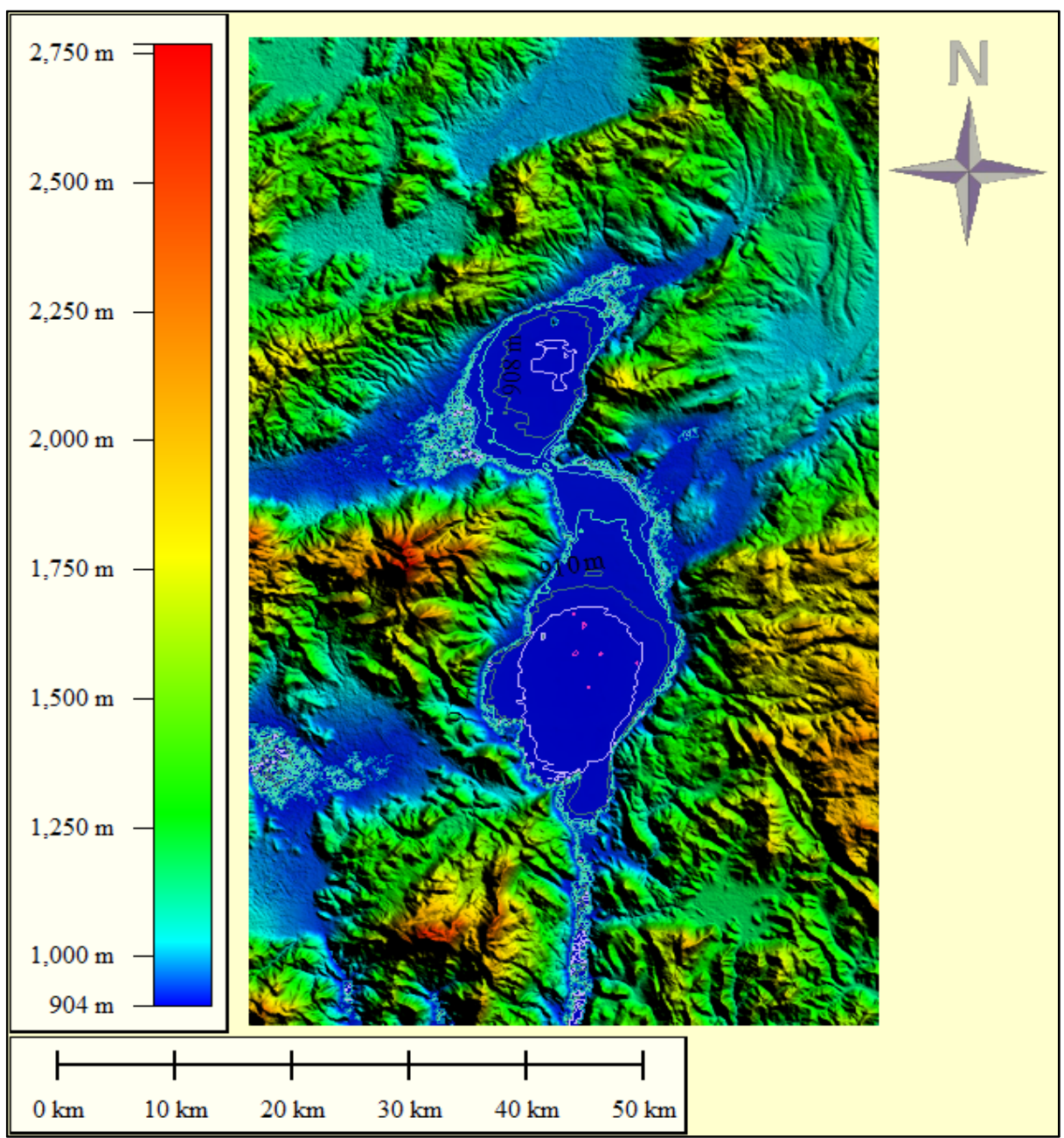

Fig 2. Map of Eğirdir Lake Bathymetry and Enclosing Topography

Natural oscillation period for lakes can be calculated by using Merian equation (Merian, 1828). Directional length of lake, L, gravitational acceleration, $g$ and average water depth, h.

$\mathrm{T}_{s}=2 \frac{\mathrm{L}}{\sqrt{\mathrm{gh}}}$

When Egirdir Lake is considered morphologically, two separated lakes that are united with a natural channel. The natural period values calculated for the north-south and east-west directions are presented in Table 1.
Table 1. Directional Natural Period for Egirdir Lake

\begin{tabular}{|l|c|c|}
\hline & N-S & E-W \\
\hline L $(\mathrm{km})$ & 48 & 17 \\
\hline $\mathrm{h}(\mathrm{m})$ & 8 & 8 \\
\hline $\mathrm{T}(\mathrm{sec})$ & 11000 & 3900 \\
\hline
\end{tabular}

Eğirdir Lake is located in the western Anatolian Fault Line within the risk zone region of $1 \mathrm{st}$ degree. Among the historical earthquakes that occurred Lakes Rigion, the most memorable of one is the $6.4 \mathrm{Ms}$, Dinar earthquake on 17 
October 1995 at 17:57 local time (UTC: 15:57). In this earthquake, a total of 90 people lost their lives and over 11000 buildings were demolished or damaged. In the Pacific Earthquake Engineering Research Center (PEER) database, the relevant earthquake records have been examined. Dinar earthquake record in Burdur station, which is the nearest earthquake recording station, is included in the study.

The records of the Dinar Earthquake for three directions in Burdur station are presented in figure 3 .
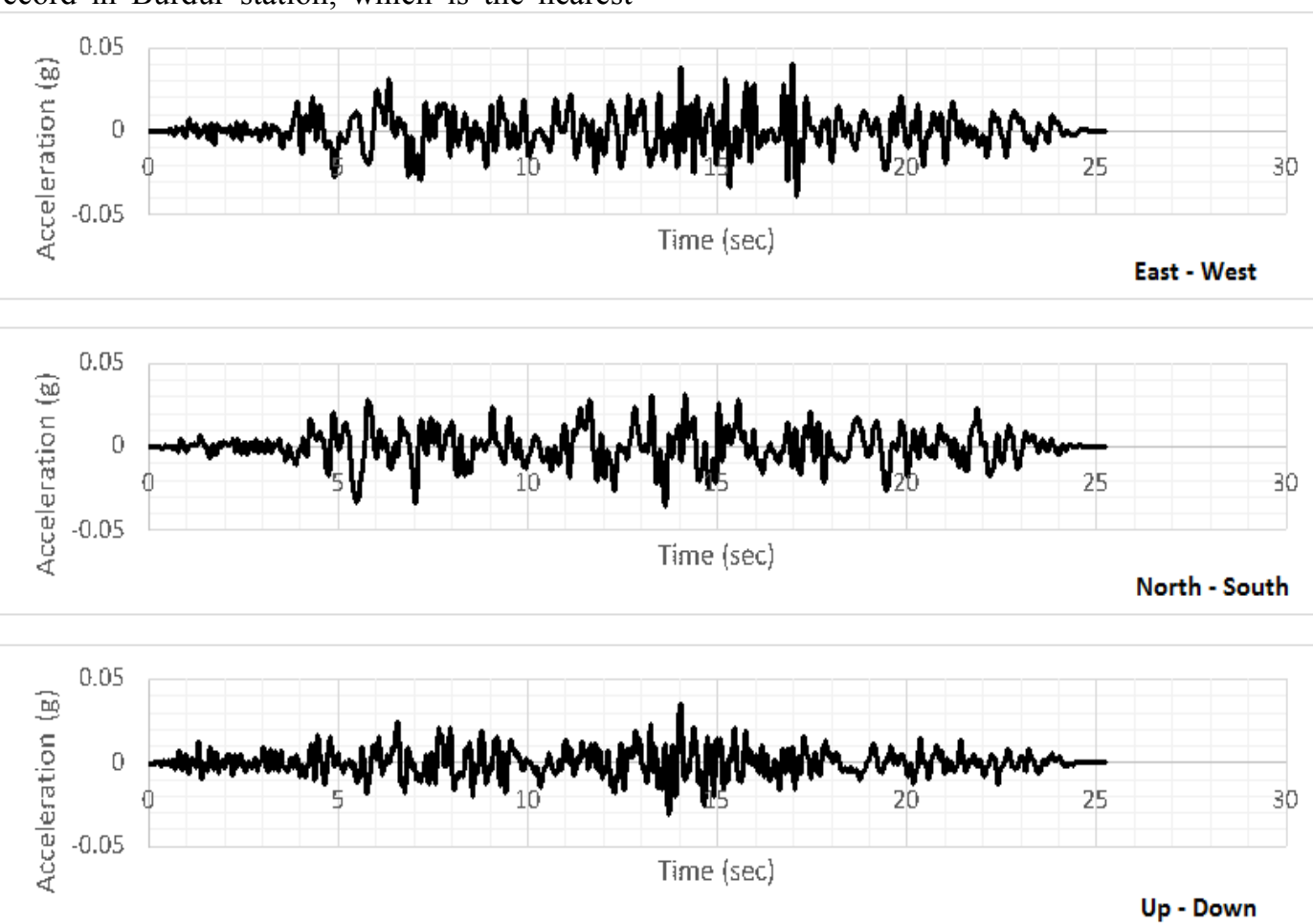

Fig 3. Dinar Earthquake Records, Burdur Station

The maximum acceleration for two horizontal and vertical directions (South - North, East West, Vertical) is almost same and the maximum acceleration is $0.035-0.04 \mathrm{~g}$. The dominant period is also approximately the same for three directions and is in the range of 0.2 0.24 seconds.

Hydrodynamic model of Eğirdir Lake for Dinar Earthquake event was carried out using lake and earthquake data.

\section{Numerical Method}

Flow-3D, commercial CFD software, solves free surface flow modelling problems rapidly in three dimensions and allows entering the earthquake data set in time series.

In order to investigate the effect of seismic oscillations for the hydrodynamic equilibrium condition prepared for Eğirdir Lake, the main assumption the lake was under hydrodynamic equilibrium and no mass transfer in and out the system.

Principal assumptions for hydrodynamic model are listed below.

- Bottom was considered impermeable.

- The water temperature was accepted at $20^{\circ} \mathrm{C}$ and the properties of the water below 1 atm pressure at $20^{\circ} \mathrm{C}$ were used.

- The flow input and output were neglected and the water level in the lake was assumed to be at the altitude of $914 \mathrm{~m}$ in the initial condition for $\mathrm{t}=0$.

- Accelerations in three directions were defined as time series and acceleration value in vertical direction was added or subtracted to gravity acceleration $(9.807 \mathrm{~m} / \mathrm{sec} 2)$. 
- RNG model was preferred as turbulence model. Previous studies have shown that the RNG turbulence model is better than the other k- $\varepsilon$ and k-w models (Kaheh, vd., 2010). in the z-direction only. After 1000 seconds, Dinar Earthquake acceleration was affected on lake water body for 25 seconds and model was run for 100000 seconds in rest.

During the first 1000 seconds, the lake was exposed to gravity acceleration of $9.807 \mathrm{~m} / \mathrm{sec} 2$

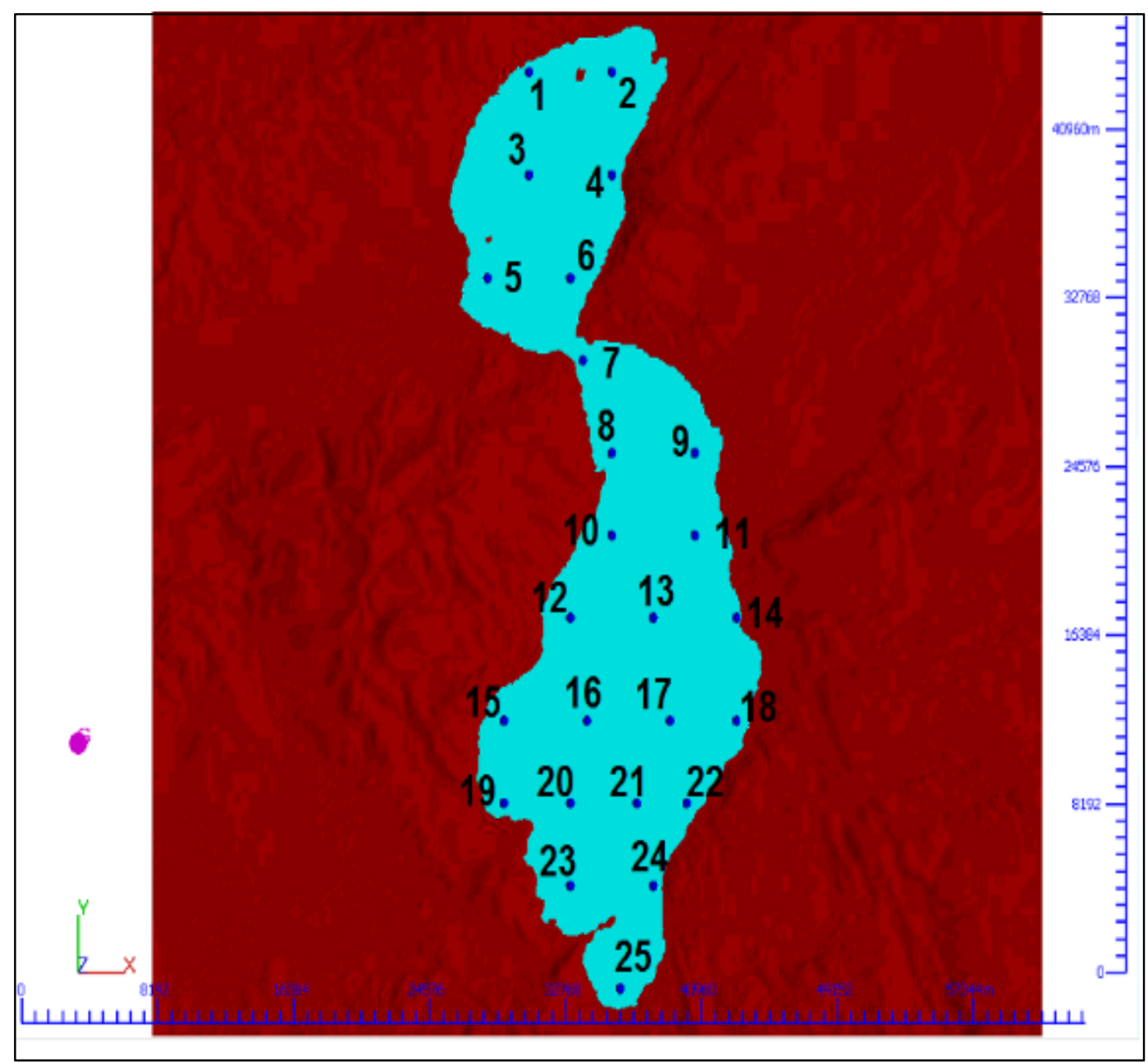

Fig 4. Observation Points for Erdemir Lake Model

In Flow-3D, its optional to define history probe for observation with coordinates in model domain and get time series information about any hydraulic parameter such as depth, velocity, free surface elevation etc.

25 history probe points for observation were defined to collect data during the analysis. Layout of the points is given in Figure 4.
Three different scenarios were performed to discuss the directional effect on seiche formation. In first scenario only the east-west direction of Dinar Earthquake was included in model. In second one, north-south direction and in the third one, three dimensional data of the earthquake was used in model. 


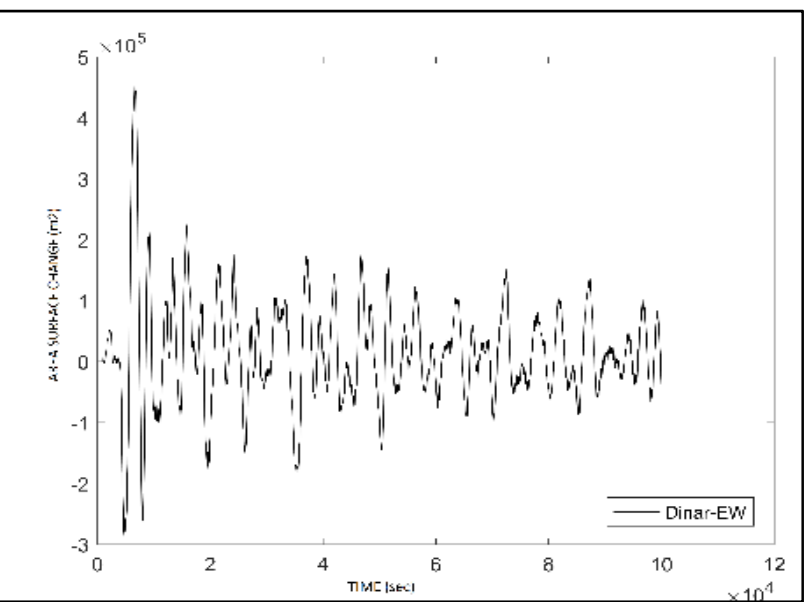

Fig 5. Egirdir Lake Surface Area Change - Dinar EW

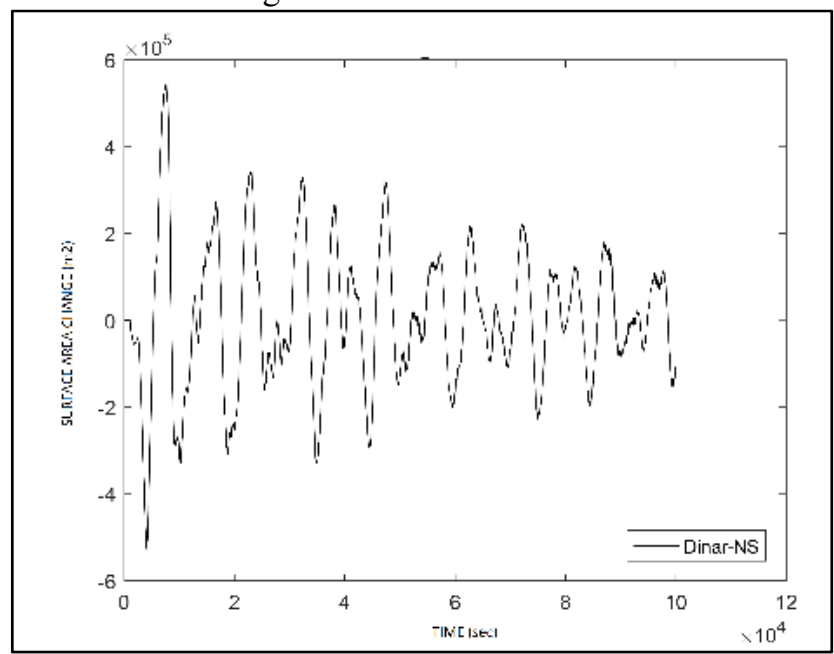

Fig 6. Egirdir Lake Surface Area Change - Dinar NS

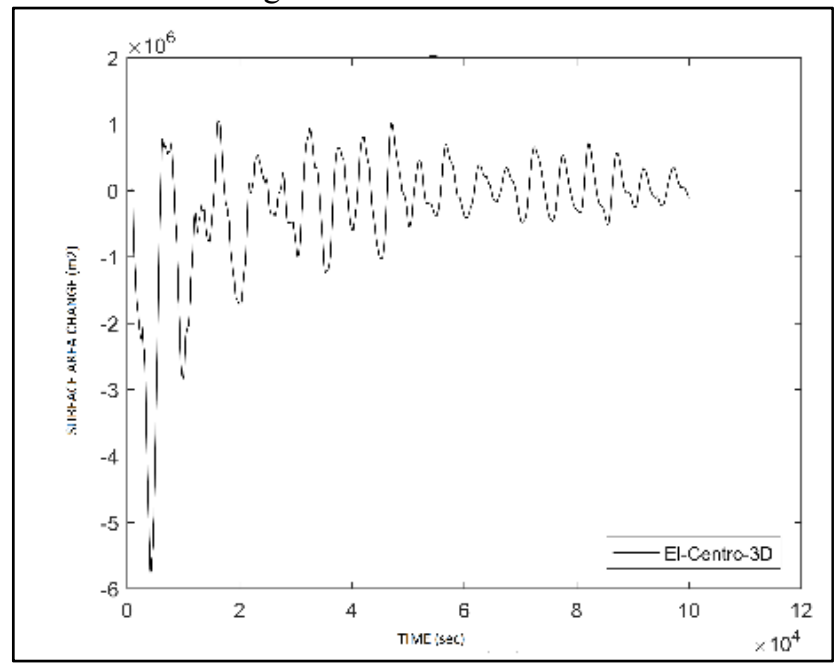

Fig 7. Egirdir Lake Surface Area Change - Dinar 3D 
Table 2. Egirdir Lake Model Scenarios

\begin{tabular}{|c|c|}
\hline Scenario No & Earthquake Direction \\
\hline 1 & East - West \\
\hline 2 & North - South \\
\hline 3 & $3 \mathrm{D}$ \\
\hline
\end{tabular}

\section{Model Results}

The model results described in the previous section was post processed in FlowSight software which is especially developed for Flow-3D and for graphical results MATLAB was used.

Water surface area change varies with time are given in Fig 5-7 depends on the earthquake signal direction. The dominant period of change over time is named as the dominant period value over time. The time series and dominant period were computed with MATLAB using the fast Fourier transform method (FFT).

\begin{tabular}{|l|c|}
\hline \multicolumn{1}{|c|}{ Scenario } & $\begin{array}{c}\text { Dominant } \\
\text { Period (sec) }\end{array}$ \\
\hline $\begin{array}{l}\text { Dinar Earthquake - EW } \\
\text { Direction }\end{array}$ & 3000 \\
\hline $\begin{array}{l}\text { Dinar Earthquake - NS } \\
\text { Direction }\end{array}$ & 8250 \\
\hline $\begin{array}{l}\text { Dinar Earthquake }-3 \\
\text { Dimensional }\end{array}$ & 8250 \\
\hline
\end{tabular}

Analytically calculated natural periods of Egirdir Lake approximately similar to modelling results. Modelling results are less than the analytical ones because of morphological effects of the lake. Dominant earthquake direction is also dominant in the results of three dimensional model.

For comparison three dimensional earthquake effects on shore and in the middle of the lake two time series graphics of water surface elevation change at point 15 and point 16 are presented in Fig 8 -9, respectively.

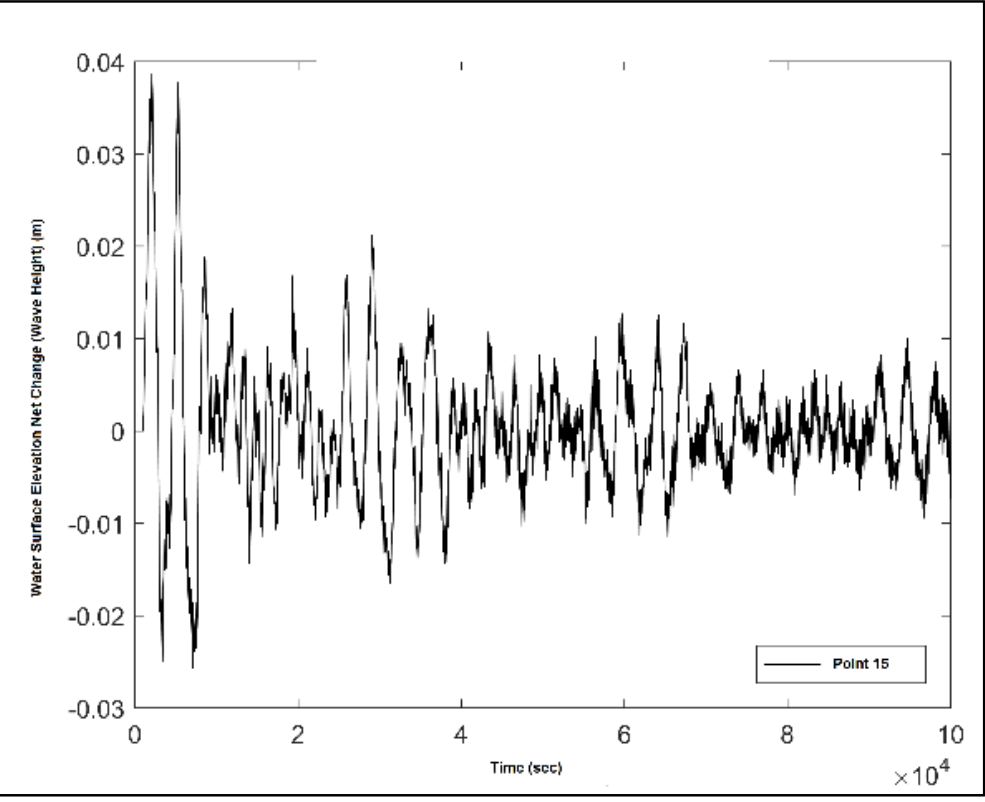

Fig 8. Point 15 Water Surface Net Change - Dinar 3D 


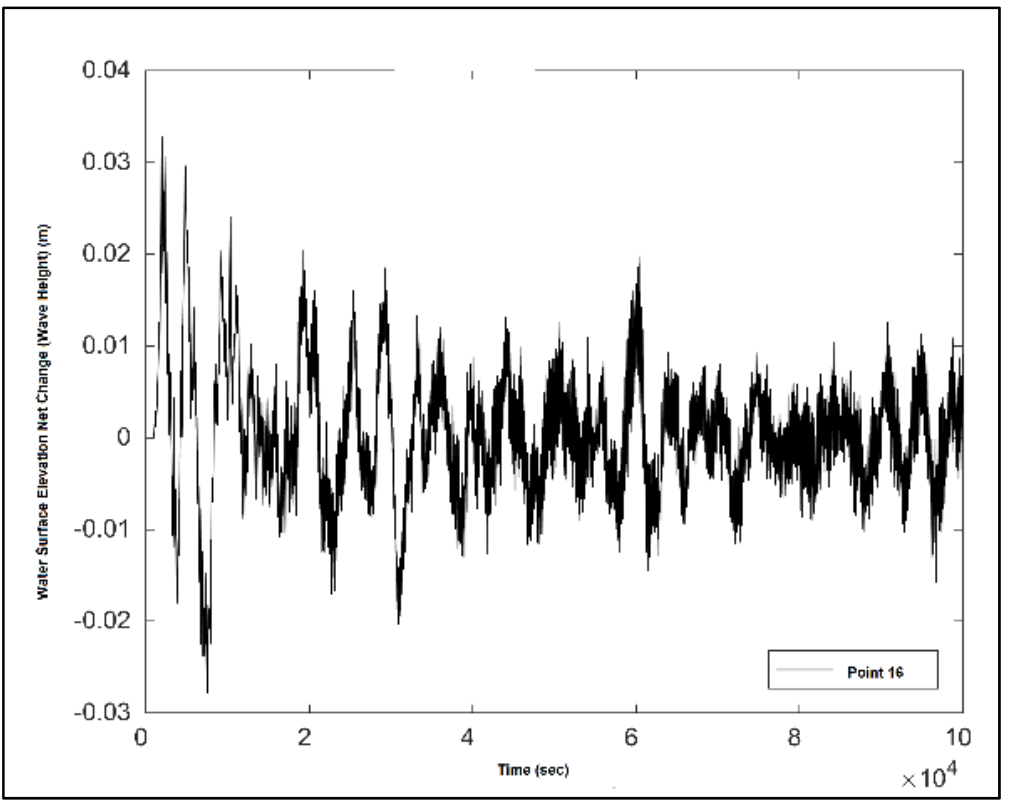

Fig 9. Point 16 Water Surface Net Change - Dinar 3D

Maximum wave height depends on earthquake induced seiches in Egirdir Lake for Point 15 and 16 were calculated as $0.06-0.07 \mathrm{~m}$. On shore because of the bathymetric effects wave height is higher than the lake center.

\section{Discussion and Conclusion}

Seismicity is an important parameter in studying the dynamics of closed/semi-enclosed water systems in the planning of infrastructures and superstructure facilities around the lake and the gulf. It is clear that the effects created by meteorological anomalies need to be investigated in addition to the immediate and short-term effects that may be caused by earthquakes in these systems.

In this study, which is carried out in order to investigate the hydrodynamic equilibrium changes under seismic oscillations of closed and / or semi-closed water bodies such as lakes and gulfs where the mixing is low and / or not at all, the hydrodynamic equilibrium state of closed and / or semi-calm water mass systems is affected by seismic oscillations. The effect has been increased and / or decreased depending on the seismic intensity and the morphological characteristics of the water mass. In addition, it has been determined that the effects of seismic oscillations in the hydrodynamic equilibrium cause effects in and around the water mass system. If the initial surface area of the lakes is assumed to be the initial condition, this surface area under the effect of the earthquake varies depending on the time during and after the earthquake. When earthquakes that affect the closed or semiclosed systems such as lakes and gulfs occur, there is a flood risk due to the earthquakes in the coastal areas in these regions.

The highest acceleration direction of the earthquake that the lakes are under influence is oscillating in a period close to the natural period in either direction. However, it is calculated that the period of lake surface area change is calculated by analyzing the results of empirically calculated natural period modeling which is accepted as rectangle flow channel.

\section{Acknowledgements}

This study is supported by Istanbul Technical University, 39777 numbered BAP Project.

\section{References}

Altınok, Y., Alpar, B., Özer, N. Aykurt, H. (2011). Revision of the tsunami catalogue affecting Turkish coasts and surrounding 
regions, Nat. Hazards Earth Syst. Sci., Vol. 11 (2): 273-291

Ambraseys, N. (2009). Earthquakes in the Mediterranean and Middle East: A Multidisciplinary Study of Seismicity up to 1900, Cambridge University Press, Cambridge, UK.

Barberopoulou, A. (2008). A Seiche Hazard Study for Lake Union, Seattle, Washington, Bulletin of the Seismological Society of America, Vol. 98, No. 4, pp. 1837-1848, August 2008.

Barberopoulou, A., A. Qamar, T. L. Pratt, K. C. Creager, and W. P. Steele (2004), Local amplification of seismic waves from the Denali Earthquake and damaging seiches in Lake Union, Seattle, Washington, Geophys. Res. Lett., 31: L03607.

Bondevik, S., B. Gjevik, and M. B. Sørensen (2013). Norwegian seiches from the giant 2011 Tohoku earthquake, Geophys. Res. Lett., 40: 3374-3378.

Gökaşan, E.; Alpar, B.; Gazioğlu, C.; Yücel Z.Y.; Tok, B.; Doğan, E. and Güneysu, C. (2001). Active tectonics of the İzmit Gulf (NE Marmara Sea): from high resolution seismic and multi-beam bathymetry data. Marine Geology, 175/1-4, 271-294.

Gulakyan, SZ. and Wilkinson, IP. (2002). The influence of earthquakes on large lacustrine ecosystems, with particular emphasis on Lake Sevan, Armenia, Hydrobiologia 472: 123-130.

Hébert H, Schindelé F, Altınok Y, Alpar B. and Gazioğlu, C. (2005) Tsunami hazard in the Marmara Sea (Turkey): a numerical approach to discuss active faulting and impact on the istanbul coastal areas. Mar Geol 215(1-2):23-43.

Kaheh, M., Kashefipour, S. M., and Dehghani, A. (2010). "Comparison of k- $\varepsilon$ and RNG k- $\varepsilon$ Turbulent Models for Estimation of Velocity Profiles along the Hydraulic Jump." 6th International Symposium on Environmental Hydraulics, Athens, Greece.

Kozac1, Ö., Altunel, E., Lindvall, S., Brankman, C. and Lettis, W. (2011). The North Anatolian Fault on Hersek Peninsula, Turkey: Its geometry and implications on the 1999 İzmit earthquake rupture propagation, Turkish J. Earth Sci. Vol.20: 359-378.
Kvale, A. (1955). Seismic seiches in Norway and England during the Assam earthquake of August 15, 1950., Siesmo. Soc. America Bull., v.45, No:2: 93-113.

McGarr, A. (1965). Excitation of seiches in channels by seismic waves., Jornal of Geophys. Research., v. 72 No: 8: 847-854.

McGarr, A. and R. C. Vorhis (1968). Seismic Seiches from the March 1964 Alaska Earthquake, U.S. Geol. Survey Prof. Paper, p. E1-E.

Merian, J.R. (1828). Ueber die Bewegung tropfbarer Flüssigkeiten in Gefässen [On the motion of drippable liquids in containers] (thesis) (in German). Basel: Schweighauser. OCLC 4622943.

Piper, A. M. (1933). Fluctuation of water surface in observation wells and at streamgaging stations in the Mokelumne area, California, during the earthquake of December 20, 1932: Am. Geophys. Union Trans. 14th Ann. Mtg: 471-475. 